\title{
A reliable in vitro fruiting system for Armillaria mellea for evaluation of Agrobacterium tumefaciens transformation vectors
}

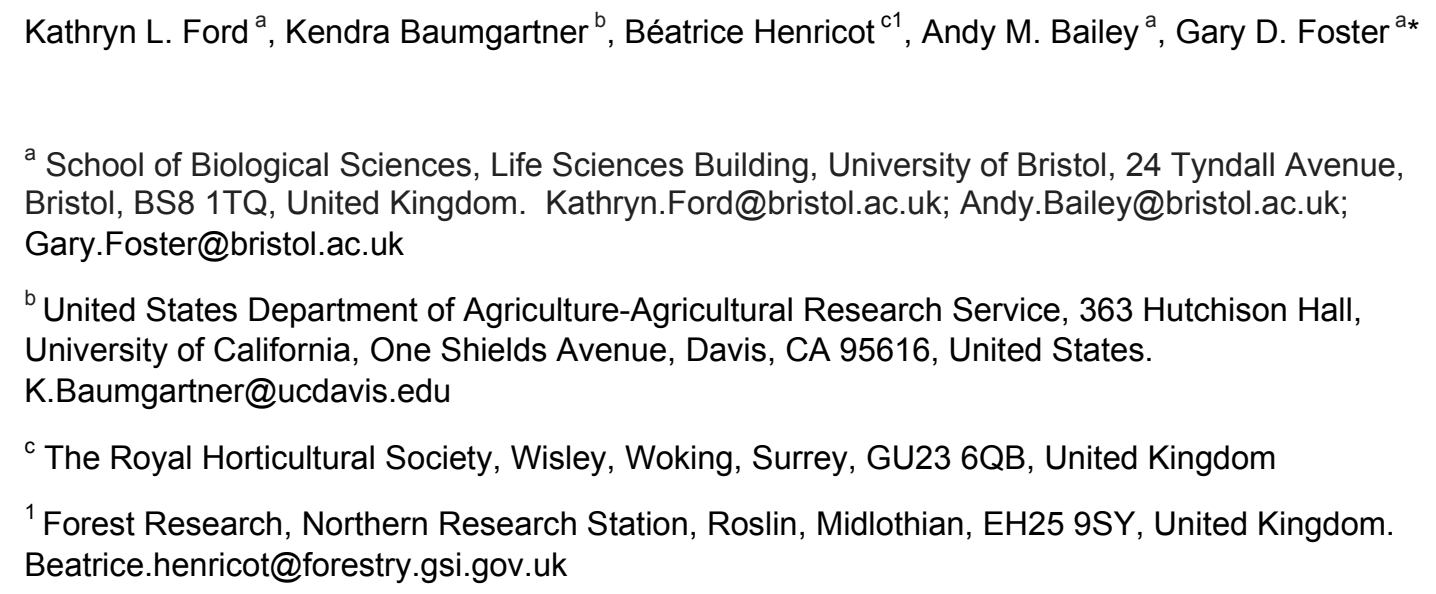

\section{Abstract}

Armillaria mellea is a serious pathogen of horticultural and agricultural systems in Europe and North America, responsible for extensive crop losses and the majority of incidents of Armillaria root disease in UK gardens. The lack of a reliable in vitro fruiting system for heterothallic $A$. mellea has hindered research and necessitated dependence on intermittently available wild-collected basidiospores of endemic, unknown genotypes, resulting in the use of variable genetic material in transformation studies. Here we describe a reliable, reproducible fruiting method to produce mature basidiocarps with viable basidiospores from in vitro cultures of heterothallic $A$. mellea from the western US. We evaluated isolates, media, light and temperature conditions to determine the most effective conditions for in vitro fruiting body production. Following colonisation of rice, sawdust and tomato medium at room temperature for four weeks, cultures were incubated in growth rooms under warm / bright conditions for four to six weeks before incubation in $\mathrm{dim} / \mathrm{cool}$ conditions to provide a light and temperature reduction. Primordia emerged within three to four weeks following a temperature decrease of at least $8^{\circ} \mathrm{C}$ and this was most efficient when coupled with a light reduction. Basidiocarps matured within three to four weeks and produced viable basidiospores. Different strains of 
Agrobacterium tumefaciens and various transformation vectors containing the hygromycin resistance gene $(h p h)$ were constructed and evaluated by transformation of in vitro-produced basidiospores. A versatile transformation vector, producing transformation efficiencies similar to the archetypal basidiomycete vector $\mathrm{pBGgHg}$, was constructed to simplify promoter and marker gene exchange using homologous recombination in yeast to facilitate future genetic work in this species. In addition, fruiting was induced in transgenic isolates and mycelial cultures established from transgenic fruiting bodies maintained hygromycin resistance. Fruiting bodies and viable basidiospores of $A$. mellea have been reliably produced in vitro which, coupled with the enhanced knowledge of suitable $A$. tumefaciens strains and vectors for transformation, will assist future genetic research into this important pathogenic species.

\section{Introduction}

Armillaria is a significant pathogen of agricultural and horticultural systems globally, causing Armillaria root disease on a wide range of species, primarily woody perennials. There are approximately 40 described species, one of which is A. mellea (Baumgartner et al. 2011). Once considered to be a polymorphic species of variable virulence present throughout the world, $A$. mellea was revealed to be a species complex, with 10 distinct species occurring across North America (Anderson \& Ullrich, 1979), including A. mellea sensu stricto. Armillaria mellea sensu stricto is also present in Europe (Korhonen, 1978), as well as in Africa and Asia. Populations across Europe and North America are heterothallic, whereas those of Japan (A. mellea ssp. nipponica) (Cha \& Igarashi, 1995) and Africa (A. mellea ssp. africana) are homothallic (Kile et al.1994), excluding recent introductions (Coetzee et al. 2001). China is the only place where both heterothallic (Chinese Biological Species K) and homothallic (CBS G) are known (Qin et al. 2007).

Armillaria mellea is one of the most virulent Armillaria species in the Northern hemisphere, responsible for annual yield losses of 10-40\% in infected vineyards in California (Baumgartner, 2004; Morrison, 2004) and identified as the primary cause of Armillaria root disease in $79 \%$ of Armillaria infections assessed in UK gardens by the RHS (RHS, 2015). The genome of $A$. mellea has recently been sequenced (Collins et al. 2013) and is available online (genome.jgi.doe.gov/Armme1_1/Armme1_1.home.html).

Problematic in vitro fruiting of Armillaria has been emphasised in the literature (Anderson, 1982; Korhonen \& Hintikka, 1974; Reaves \& McWilliams, 1991; Rhoads, 1925; Rhoads 1945; Shaw et al. 1981). Indeed, the few successful reports of fruiting in A. mellea sensu stricto are mainly concerning homothallic subspecies from Japan (A. mellea spp. nipponica) (Ota et al.1998), Korea (likely to be $A$. mellea spp. nipponica) (Shim et al. 2006) and Africa (A. mellea spp. africana) (Abomo-Ndongo et al. 1997).

The ability to fruit $A$. mellea in culture ensures the regular supply of basidiospores for 
so there is some interest in deliberate cultivation. In this paper we describe a reliable, reproducible in vitro fruiting system for heterothallic $A$. mellea from the western US, and demonstrate the importance of a light and temperature reduction for primordia production, in accordance with fruiting requirements in other basidiomycetes (Kües \& Liu, 2000). Agrobacterium tumefaciens-mediated transformation of A. mellea relies on the use of basidiospores (Baumgartner et al. 2010) and here we also evaluate the efficacy of $A$. tumefaciens strains and vectors, known to have varying efficiencies in other basidiomycetes (Burns et al. 2006; Collins et al. 2010; Heneghan et al. 2009; Kilaru et al. 2006; Kilaru et al. 2009), to explore their potential for use in future transformation studies.

\section{Methods}

\subsection{Strains and culture conditions}

Isolates of $A$. mellea (heterothallic and homothallic) and $A$. gallica were obtained from collections held at the Royal Horticultural Society, Wisley, UK and the United States Department of AgricultureAgricultural Research Service, Davis, USA (Table 1). Wild-type isolates were originally identified by pairing with haploid testers (Guillaumin et al. 1991) or amplification of the IGS1 region and subsequent digestion with Alul (Harrington \& Wingfield, 1995). Isolates were routinely maintained on potato dextrose agar (PDA) at $25^{\circ} \mathrm{C}$ in the dark. Saccharomyces cerevisiae strain $\mathrm{Y} 10000$ was used for plasmid construction by homologous recombination and was maintained on yeast peptone dextrose agar (YPDA) at $28^{\circ} \mathrm{C}$. Escherichia coli strain DH5a was used for subcloning plasmids and Agrobacterium tumefaciens strains AGL-1 and LBA1126 were used in A. tumefaciens-mediated transformation of $A$. mellea.

\subsection{Fruiting media and growth room conditions}

Several different media were evaluated to induce fruiting bodies. Media were prepared freshly on the day of use in 1 litre wide mouth jars (VWR) and the sawdust was a softwood pet bedding. The following media were utilised: Orange medium: two oranges (roughly chopped) and $500 \mathrm{ml}$ water (Reaves \& McWilliams, 1991); Rice, sawdust and carrot (RSC): $30 \mathrm{~g}$ rice, $15 \mathrm{~g}$ sawdust, $150 \mathrm{ml}$ water and $1 \mathrm{~cm}$ top layer of homogenised carrot (Shim et al. 2006): Rice, sawdust and peptone (RSP): $30 \mathrm{~g}$ rice, $15 \mathrm{~g}$ sawdust and $150 \mathrm{ml}$ of $0.6 \%$ peptone solution (Grillo et al. 2000); Rice, sawdust and tomato (RST): $30 \mathrm{~g}$ rice, $15 \mathrm{~g}$ sawdust, $150 \mathrm{ml}$ water and $1 \mathrm{~cm}$ top layer of homogenised tomato; Rice, sawdust, pearl barley, corn and carrot (RSBCC): $20 \mathrm{~g}$ rice, $10 \mathrm{~g}$ sawdust, $10 \mathrm{~g}$ pearl barley, $10 \mathrm{~g}$ corn kernels, $150 \mathrm{ml}$ water and $1 \mathrm{~cm}$ top layer of homogenised carrot. Media were inoculated with mycelial agar plugs from a four-week Armillaria culture and incubated at room temperature in the dark for four weeks, or until the mycelium had fully colonised the medium. After colonisation, the cultures were moved into their respective growth rooms for incubation with $70 \%$ relative humidity and photoperiods, temperatures and light intensities appropriate to the required experimental conditions. The growth 
rooms were fitted with fluorescent lights with adjustable light intensities and cultures were wrapped in aluminium foil when complete darkness was required. Cultures were examined weekly for the presence of primordia.

Following production of fruiting bodies, basidiocarps were harvested and placed gills down on a clean black piece of paper, covered with a plastic tub and left for 24 hours in a cool room to obtain a spore print. The basidiospores were then scraped off the paper using a sterile wire loop, suspended in sterile deionised water and stored at $4^{\circ} \mathrm{C}$ until use. Basidiospores remained viable and transformable for at least two years post harvesting.

\subsection{Vector construction and Agrobacterium tumefaciens transformation}

Plasmid pBGgHg (Chen et al. 2000) is based on pCAMBIA and contains the full length hygromycin resistance gene, $h p h$, under the control of the Agaricus bisporus gpdll promoter with the CaMV 35S terminator. Plasmid pGR4-4iGM3 (Burns et al. 2005), is based on pGreen and contains the truncated $h p h$ gene (where the first two lysine residues of the coding region are deleted) driven by the $A$. bisporus gpdII promoter with the Aspergillus nidulans trpC terminator.

Yeast homologous recombination using the LiOAc transformation method (Gietz \& Woods, 2002) was used to adapt the $A$. tumefaciens binary vector pCAMBIA0380 with the $2 \mu$ origin of replication and the URA3 gene for plasmid maintenance and selection in a ura3 mutant $S$. cerevisiae strain for use as a backbone vector (pCAMBIA0380YA) (Ali, 2015) in the construction of plasmids pCAM-hph-Pcgpd and pCAM-hph-series (Supplementary Figure 1). pCAM-hph-Pcgpd (containing the Phanerochaete chrysosporium gpd promoter, truncated hph gene and A. nidulans trpC terminator) and pCAM-hphseries (containing the $A$. bisporus gpd promoter, full length hph gene and CaMV 35S terminator) were designed in Clone Manager (Sci-Ed Software). The backbone vector pCAMBIA0380YA was linearised by digestion with BamHI and PCR was performed using Phusion DNA polymerase (Thermo Scientific) and primers listed in Supplementary Table 1 to amplify the required DNA fragments from other plasmids for use in yeast homologous recombination to construct the vectors. Primers were designed to include a 30 bp overlap between the PCR fragments to allow recombination in yeast. Phusion PCR was performed at $98^{\circ} \mathrm{C}$ for 30 seconds, followed by 36 cycles of $98^{\circ} \mathrm{C}$ for 10 seconds, $55^{\circ} \mathrm{C}$ for 30 seconds, $72^{\circ} \mathrm{C}$ for 45 seconds with a final cycle of $72^{\circ} \mathrm{C}$ for 10 minutes.

Plasmids were extracted from S. cerevisiae cells using Zymoprep Yeast Plasmid Miniprep II (Zymo Research), rescued into competent E. coli and verified by PCR using LB/RB primers (Supplementary Table 1), restriction digestion and sequence analysis. Correctly constructed plasmids were transformed into competent $A$. tumefaciens by electroporation.

Agrobacterium tumefaciens-mediated transformation of $A$. mellea was performed as per Baumgartner et al. (2010) using strains AGL-1 (Lazo et al. 1991) and LBA1126 (Bundock et al. 1995) carrying the four plasmids (Table 2). Putative transformants were subcultured on to PDA plates containing 200 $\mu \mathrm{g} / \mathrm{ml}$ timentin and $30 \mu \mathrm{g} / \mathrm{ml}$ hygromycin. One-way analysis of variance (ANOVA) was performed in 
SPSS to determine the effects of $A$. tumefaciens strain (AGL-1, LBA1126), vector (pBGgHg, pGR44iGM3, pCAM-hph-Pcgpd, pCAM-hph-series), and their combination on the efficiency of transformation. Means were compared for significant main effects $(P \geq 0.05)$ using Tukey's HSD test in SPSS.

\subsection{Confirmation of transgene presence in putative transformants}

DNA was extracted from two-week PDB cultures using the protocol described by Liu et al. (2000) and PCR was performed using hph primers (Supplementary Table 1) to confirm presence of the transgene. The cycle used was 2 minutes at $94^{\circ} \mathrm{C}$ followed by 30 cycles of 30 seconds at $94^{\circ} \mathrm{C}, 30$ seconds at $58^{\circ} \mathrm{C}, 60$ seconds at $72^{\circ} \mathrm{C}$ with a final cycle of $72^{\circ} \mathrm{C}$ for 10 minutes.

\section{Results}

\subsection{Preliminary production of fruiting bodies}

A variety of media and isolate combinations were used in the preliminary experiments in order to induce fruiting in isolates of $A$. gallica and $A$. mellea present in our collection (Table 3). All isolates were able to colonise all media after four weeks in darkness at room temperature ( 20 to $25^{\circ} \mathrm{C}$ ). Following transfer into growth rooms with a photoperiod of $12 \mathrm{~h}$ light / $12 \mathrm{~h}$ dark and temperature $15^{\circ} \mathrm{C}$, primordia were induced in cultures of $A$. gallica isolate CG645 and heterothallic $A$. mellea isolates CG440, ELDO17 and ELDO19 and these primordia developed into immature fruiting bodies in CG440 and ELDO19 but did not develop further. ELDO17 produced immature fruiting bodies on RSC, RST and RSBCC and mature fruiting bodies were obtained from the RST medium (Figure 1). All other isolates that produced primordia could do so on the RST medium. Primordia production appeared to be dependent upon a reduction in light intensity, photoperiod or temperature.

\subsection{Establishment of an effective medium and light and temperature conditions}

In order to establish an effective in vitro fruiting system for heterothallic $A$. mellea, experiments proceeded with heterothallic isolates ELDO17 and ELDO19 collected from the western US. In the preliminary experiments, primordia were only produced following a combined light and temperature reduction; therefore, an experiment was devised to determine whether this was a requirement for primordia induction. Three media were compared: RST, RSC and RSP, and cultures underwent a light and temperature reduction from $23^{\circ} \mathrm{C}$ to $15^{\circ} \mathrm{C}$, photoperiod of $16 \mathrm{~h}$ light / $8 \mathrm{~h}$ dark to $10 \mathrm{~h}$ light / $14 \mathrm{~h}$ dark and light intensity from 125 to $5 \mu \mathrm{mol} \mathrm{m} \mathrm{m}^{-2} \mathrm{~s}^{-1}$. Negative controls were cultures that were maintained in constant conditions of $15^{\circ} \mathrm{C}$ and $5 \mu \mathrm{mol} \mathrm{m} \mathrm{m}^{-2}$ light intensity with a photoperiod of $10 \mathrm{~h}$ light / $14 \mathrm{~h}$ dark. The experiments were repeated at least twice with five cultures of each isolate in total as a minimum. ELDO17 produced primordia on all three media tested and on RST most frequently (96\%), whereas for ELDO19, primordia were produced on RSC (56\%) and RST (79\%), but not on RSP (Figure 2). No primordia developed in the control cultures, which did not undergo a light 
and temperature reduction. Cultures usually produced several hundred primordia per pot and five to thirty of these progressed to immature fruiting bodies, with between one and five of these reaching maturity. Primordia of ELDO17 developed into mature fruiting bodies more regularly on RST (75\%) than on RSC (22\%), and not at all on RSP. ELDO19 only developed mature fruiting bodies on RSC, and very infrequently (11\%) (Figure 2). Mature fruiting bodies usually developed within three weeks and basidiospores were viable and could be collected from all mature fruiting bodies providing that the caps were fully expanded and the spore print was taken in cool conditions ( 15 to $20^{\circ} \mathrm{C}$ ). Monosporous progeny of ELDO17 and ELDO19 exhibited a white fluffy morphology indicative of a haploid culture.

\subsection{Uncoupling of light and temperature requirements for ELDO17 fruiting body production}

Further experiments were conducted to separate the effects of light and temperature on the development of fruiting bodies. In one experiment, initial colonisation temperature $\left(18^{\circ} \mathrm{C}, \mathrm{RT}^{\circ}\right.$ or $\left.25^{\circ} \mathrm{C}\right)$ had no effect on the timing or incidence of primordia production, but primordia did not develop into mature fruiting bodies if initially colonised at $18^{\circ} \mathrm{C}$. Colonisation in the light reduced the proliferation of rhizomorphs in comparison to colonisation in darkness but did not affect fruiting body production. Variation of photoperiod in the warm / bright growth room from 8 to 16 hours of light and variation in temperature from $23^{\circ} \mathrm{C}$ to $28^{\circ} \mathrm{C}$ had no effect on the production of fruiting bodies, but at least four weeks' incubation in warm / bright conditions before decreasing the light and temperature was essential for primordia initiation.

To determine whether reduction in light or a reduction in temperature was responsible for primordia induction, RST medium was colonised with ELDO17 for four weeks (at RT unless specified) and the cultures were then incubated in thirteen conditions for six weeks (Table 4), before being incubated in an additional condition if required, awaiting emergence of primordia (Figure 3). This experiment was performed with three to six replicates for the various conditions.

All positive control cultures (condition 6) with the optimal parameters of warm / bright conditions of $23^{\circ} \mathrm{C}, 125 \mu \mathrm{mol} \mathrm{m} \mathrm{s}^{-2}$ light for six weeks followed by cool / dim conditions of $15^{\circ} \mathrm{C}, 5 \mu \mathrm{mol} \mathrm{m}^{-2} \mathrm{~s}^{-1}$ light produced mature fruiting bodies. No primordia were produced in cultures maintained in constant conditions of $15^{\circ} \mathrm{C}$ or $23^{\circ} \mathrm{C}$ and $5 \mu \mathrm{mol} \mathrm{m} \mathrm{s}^{-1}$ light, $125 \mu \mathrm{mol} \mathrm{m} \mathrm{m}^{-1}$ light (conditions $1,2,11,12$ ) or darkness (conditions 3 and 13) that did not experience a light or temperature reduction, nor in cultures maintained in darkness with a temperature reduction (condition 8). A temperature decrease was crucial for primordia initiation, and a light reduction was also important. At $23^{\circ} \mathrm{C}$ a light reduction from $125 \mu \mathrm{mol} \mathrm{m} \mathrm{m}^{-2}$ to $5 \mu \mathrm{mol} \mathrm{m} \mathrm{s}^{-1}$ was unable to induce fruiting (condition 4), whereas at $15^{\circ} \mathrm{C}$ a light reduction was sufficient for fruiting induction if colonisation occurred initially at RT (condition 9) (67\% of cultures fruited) but not at $15^{\circ} \mathrm{C}$ (condition 10). A temperature reduction alone from $23^{\circ} \mathrm{C}$ to $15^{\circ} \mathrm{C}$ was sufficient to induce primordia at $125 \mu \mathrm{mol} \mathrm{m} \mathrm{m}^{-2}$ (condition 7 ) (33\% of cultures fruited) and 5 $\mu \mathrm{mol} \mathrm{m} \mathrm{m}^{-1}$ (condition 5$)(50 \%$ of cultures fruited). 
Following successful fruiting by heterothallic isolates, attempts were made to fruit homothallic isolates of $A$. mellea from Japan, China and Africa (Table 5) using the optimal conditions identified for heterothallic isolate ELDO17. After four weeks colonisation of RST medium at room temperature, the cultures were moved into the first condition of warm / bright conditions of $23^{\circ} \mathrm{C}, 125 \mu \mathrm{mol} \mathrm{m} \mathrm{m}^{-2} \mathrm{~s}^{-1}$ light, $16 \mathrm{~h}$ light / $8 \mathrm{~h}$ dark for six weeks, followed by cool / dim conditions of $15^{\circ} \mathrm{C}, 5 \mu \mathrm{mol} \mathrm{m} \mathrm{m}^{-2} \mathrm{~s}^{-1}$ light for 10 $\mathrm{h}$ light / $14 \mathrm{~h}$ dark awaiting primordia emergence. Negative controls were cultures maintained in constant conditions of $15^{\circ} \mathrm{C}, 5 \mu \mathrm{mol} \mathrm{m} \mathrm{m}^{-2} \mathrm{~s}^{-1}$ light, $10 \mathrm{~h}$ light $/ 14 \mathrm{~h}$ dark.

Fruiting bodies were produced from all isolates from Africa (03468/T1, 03469/T1 and 03470/T1) and the Japanese isolate (03384/2) (Figure 1), but not from the Chinese isolates (03332/2, 03345/1 and 03371/1). In contrast to heterothallic A. mellea, all African and Japanese isolates produced fruiting bodies when maintained in control conditions without a combined light and temperature reduction. Monosporous progeny of homothallic isolates had a flat, crustose morphology typical of a diploid culture.

\subsection{Timing of primordia emergence}

The timing of primordia emergence was recorded throughout the experiments and was found to vary between isolates. Primordia of ELDO17 were usually produced 23 days after a light and temperature reduction and 25 days after across all heterothallic cultures on average, whereas primordia induction in homothallic cultures generally took longer and was more variable (38 days). The number of days taken for primordia to appear in heterothallic cultures after a light and temperature reduction and the number of days after being moved to the growth rooms that primordia appeared in homothallic cultures (since primordia production was not dependent on a light or temperature reduction in these isolates) is shown in Figure 4.

Fruiting bodies of homothallic cultures developed more quickly (two weeks) than those of heterothallic cultures (three weeks) and the minimum time taken from inoculation of medium to harvesting basidiospores was 97 days for homothallic cultures and 107 days for heterothallic cultures. In some cases, two 'flushes' of homothallic $A$. mellea fruiting bodies could be obtained from one culture without altering the growth conditions, whereas new primordia that developed in cultures of heterothallic $A$. mellea after the first flush of fruiting bodies did not develop further.

\subsection{Evaluation of hygromycin resistance vectors}

261 Once a robust system for producing fruiting bodies in vitro was established, basidiospores were 
hygromycin resistance has been reported previously using $A$. tumefaciens AGL-1 and plasmid pBGgHg (Baumgartner et al. 2010) and this plasmid was used to transform A. mellea in addition to another plasmid previously utilised to transform basidiomycetes, pGR4-4iGM3 (Burns et al. 2005), and two plasmids constructed in this research, pCAM-hph-Pcgpd and pCAM-hph-series, in order to investigate transformation efficiency of $A$. tumefaciens strains and vectors. Transformations were performed at least twice for each strain and vector combination and the transformation efficiency was evaluated for A. tumefaciens strains AGL-1 and LBA1126 with the four plasmids. Agrobacterium tumefaciens strain LBA1126 was able to transform A. mellea with a similar efficiency to AGL-1, producing four and three transformants per transformation plate, respectively. The gpd promoter from $P$. chrysosporium was capable of driving hph expression and yielded a similar number of transformants to plasmids with the A. bisporus promoter driving hph (generating three and four transformants per transformation plate, respectively). PCR analysis showed the presence of the hph gene in all transformants tested and serial transfers on to PDA with $30 \mu \mathrm{g} / \mathrm{ml}$ hygromycin resulted in no loss of hygromycin resistance. Three colonies transformed with each plasmid were selected and subcultured in triplicate on to PDA with $30 \mu \mathrm{g} / \mathrm{ml}$ hygromycin to evaluate efficacy of transgene expression. Colonies transformed with a plasmid containing the full length $h p h$ gene demonstrated significantly faster growth after three weeks (according to Tukey's HSD test following one-way ANOVA), indicated by a larger colony diameter in comparison to colonies transformed with the truncated hph gene (Figure 5).

\subsection{Fruiting body production in transgenic isolates}

Fruiting was attempted in RST medium (Table 5) with selected transgenic isolates of $A$. mellea with diploid morphology produced in this study and transgenic isolates produced in previous work (Baumgartner et al. 2010) to assess stability of the transgene.

Isolates produced by pairing six different haploid transgenic isolates generated during transformation with plasmid $\mathrm{pBGgHg}$ of basidiospores from wild-harvested isolate Son202 with diploid wild-type NAPA187 that are believed to be triploid or aneuploid according to microsatellite data (Napa187xR1PT2 to Napa187xR2PT3) (Baumgartner et al. 2010) did not fruit. In contrast, transformants with either $\mathrm{pBGgHg}$ or pCAM-hph-series, which were generated from basidiospores from in vitro-produced fruiting bodies of ELDO17 and were diploid based on morphology (pB1 to 16.1), produced primordia 26 days after a light and temperature reduction. Primordia developed into immature fruiting bodies and mycelial cultures established from the stipe, pileus and gill tissue of the transgenic fruiting bodies maintained hygromycin resistance, verified by serial subcultures on to PDA with $30 \mu \mathrm{g} / \mathrm{ml}$ hygromycin. 


\subsection{In vitro production of fruiting bodies}

302 An effective method of producing in vitro fruiting bodies has been established for heterothallic $A$.

303 mellea from the western US. Previously recalcitrant to fruiting in vitro, this protocol for fruiting $A$.

304 mellea is reliable and repeatable and has produced mature fruiting bodies of two heterothallic western

305 US isolates, ELDO17 and ELDO19, four homothallic isolates (03468/T1, 03469/T1, 03470/T1 and

306 03384/2) and immature fruiting bodies of a heterothallic UK isolate, CG440. A medium consisting of

307 rice, sawdust and tomato (RST) was shown to be the most effective, and of the heterothallic isolates,

308 ELDO17 fruited most reliably. The optimal parameters for in vitro fruiting in heterothallic isolate

309 ELDO17 were determined to be the following: RST medium colonisation at room temperature for four

310 weeks followed by warm / bright conditions of $23^{\circ} \mathrm{C}, 125 \mu \mathrm{mol} \mathrm{m} \mathrm{m}^{-2} \mathrm{~s}^{-1}$ light, $16 \mathrm{~h}$ light $/ 8 \mathrm{~h}$ dark for six

311 weeks, followed by cool / dim conditions of $15^{\circ} \mathrm{C}, 5 \mu \mathrm{mol} \mathrm{m} \mathrm{m}^{-2} \mathrm{~s}^{-1}$ light, $10 \mathrm{~h}$ light $/ 14 \mathrm{~h}$ dark. Primordia

312 appeared within three to four weeks after a light and temperature decrease and fruiting bodies

313 matured within an additional three to four weeks. Primordia were only induced three to four weeks

314 after a temperature reduction in cultures exposed to light and this was most successful with a

315 simultaneous decrease in light intensity. Mature fruiting bodies with viable basidiospores were

316 obtained in less than four months at any time of year.

317 Fruiting body development in basidiomycetes is usually induced by a substantial change in

318 environmental conditions, often light and temperature. In several species such as Pleurotus

319 ostreatus, Schizophyllum commune, Lentinula edodes and Flammulina velutipes, fruiting is controlled

320 as least partially by light, which has been shown to influence hyphal aggregation required for

321 primordia formation and affect maturation of the basidiocarp (Arjona et al. 2009; Kües \& Liu, 2000;

322 Nakazawa et al. 2008). In other species such as $A$. bisporus, fruiting is not light-regulated and is

323 dependent upon a temperature reduction of at least $5^{\circ} \mathrm{C}$. Coprinopsis cinerea, $L$. edodes and $F$.

324 velutipes also require a temperature reduction in order to induce fruiting (Eastwood et al. 2013; Kües

325 \& Liu, 2000; Nakazawa et al. 2008).

326 A requirement for a temperature reduction to induce primordia has been reported previously in

327 Armillaria, in an undescribed species from Africa, where cultures colonised at $25^{\circ} \mathrm{C}$ required a

328 temperature decrease to $20^{\circ} \mathrm{C}$ to initiate primordia development (Otieno et al. 2003). Fruiting in other

329 Armillaria species, however, does not appear to be reliant upon a temperature reduction, or perhaps

330 the higher colonisation temperature prior to movement into cooler growth rooms provides a sufficient

331 temperature decrease. For example, the majority of protocols for fruiting other Armillaria species

332 stipulate colonisation in the dark between $20-27^{\circ} \mathrm{C}$ and then incubation in $12 \mathrm{~h}$ light $/ 12 \mathrm{~h}$ dark at $12-$

$33325^{\circ} \mathrm{C}$ awaiting primordia emergence (Grillo et al. 2000; Ota et al. 1998; Otieno et al. 2003; Pérez-

334 Sierra et al. 2004; Reaves \& McWilliams, 1991; Shim et al. 2006); sometimes providing a temperature

335 reduction between colonisation and incubation. Other protocols have maintained cultures in constant

336 light at $20-23^{\circ} \mathrm{C}$ during colonisation and incubation (Shaw et al. 1981) or colonised the medium at

$33723^{\circ} \mathrm{C}$ and incubated cultures in the laboratory without controlling light and temperature (Abomo-

338 Ndongo et al. 1997) so that a temperature decrease does not occur. Furthermore, with the exception 
of cultures maintained on a laboratory bench that may have experienced a decrease in day length, none of these protocols used by other researchers appears to have provided a light reduction, since colonisation occurred in the dark. As this research has shown that primordia induction in heterothallic A. mellea requires a temperature decrease, and colonisation at a higher temperature prior to transfer into a cooler growth room provides an insufficient temperature decrease to induce primordia unless a light reduction is also provided, any attempted fruiting of heterothallic $A$. mellea using these conditions is unlikely to have succeeded.

In correlation with previous studies, homothallic isolates of $A$. mellea from Japan, and from Africa (which are intercompatible, likely to have originated from Japan and one of which has been fruited previously (Abomo-Ndongo et al. 1997; Baumgartner et al. 2012), fruited with no light or temperature reduction or with only a reduction in temperature between colonisation and incubation. The reasons for this remain elusive but similar fruiting conditions have been described for other Armillaria species (Grillo et al. 2000; Reaves \& McWilliams, 1991; Shim et al. 2006) and are possibly reflective of the seasonal conditions of their natural habitats. The homothallic isolates of $A$. mellea from China (CBS $\mathrm{G}$ ), heterothallic A. mellea isolate NAPA187 and A. gallica isolates ANA220, CG024 and CG263 did not fruit in this study, and heterothallic A. mellea isolate CG440 and A. gallica isolate CG645 only produced immature fruiting bodies and primordia, respectively. It is possible that a longer duration of warm / bright conditions or a sharper temperature decrease would induce primordia in these isolates, or different medium may be more effective, since fruiting body production in ELDO17 and ELDO19 varied according to medium and A. gallica has been fruited on RSP previously (Grillo et al. 2000; Reaves \& McWilliams, 1991) but this medium was only attempted with one A. gallica isolate in this study. Alternatively, these isolates may not be fully fertile and so unable to produce mature fruiting bodies irrespective of the conditions.

\subsection{Evaluation of Agrobacterium tumefaciens transformation vectors and transgenic isolates}

The production of $A$. mellea fruiting bodies in vitro facilitates research requiring regular availability of basidiospores. In this study, we have shown that in vitro produced basidiospores from isolate ELDO17 can be transformed by $A$. tumefaciens strains LBA1126 and AGL-1 with similar efficiencies to produce hygromycin resistant colonies, using both the full length and truncated $h p h$ gene, and verified that the $P$. chrysosporium gpd promoter is able to drive $h p h$. This is significant because the truncated $h p h$ gene is unable to confer hygromycin resistance in some basidiomycetes such as $C$. cinerea and Clitopilus passeckerianus (Kilaru et al. 2009), yet we have shown that it can confer hygromycin resistance in $A$. mellea, albeit at lower efficiencies than the full length version of the gene. This decrease in hygromycin resistance with vectors that contain the truncated version of the hph gene, demonstrated by slower growth of transformed colonies, is attributed to the deletion of two lysine residues at the 5' end of the $h p h$ gene, reducing the efficacy of hygromycin deactivation. As certain promoters are unable to drive hph in A. bisporus and C. cinerea (Burns et al. 2005, Burns et al. 2006), the ability of the $P$. chrysosporium gpd promoter to drive hph in $A$. mellea is also important and will increase the availability of functional promoters for genetic work in A. mellea. Furthermore, 
the construction of plasmid pCAM-hph-series, demonstrating similar transformation efficiencies to the commonly used basidiomycete vector $\mathrm{pBGgHg}$ and simplifying promoter and marker gene exchange by the use of the yeast homologous recombination system, will facilitate future genetic studies in $A$. mellea.

The transgenic isolates derived from ELDO17 generated in this work could be induced to produce immature fruiting bodies, and mycelial cultures established from fruiting body tissues maintained hygromycin resistance. Growth arrested in transgenic fruiting bodies a few days before maturity, in a similar way to that observed in wild-type isolates on occasion, and no basidiospores were obtained. Since ELDO17 is heterothallic and sibling mating between monosporous progeny during coincubation of the basidiospores and $A$. tumefaciens probably gave rise to the diploid mycelium, it is probable the genetically variable progeny will have variable, and possibly reduced, fertility, so the maturation of fruiting bodies is more likely in some progeny than in others. Isolates that were produced via pairing of haploid transgenic isolates derived from Son202 with wild-type diploid isolate NAPA187 (Baumgartner et al. 2010) that are believed to be triploid or aneuploid did not produce primordia, possibly due to the their ploidy status leading to complications in fruiting, or because in vitro fruiting was not successful in parent isolate NAPA187 and therefore is less likely to succeed in its progeny, and in vitro fruiting has not been attempted in parent isolate Son202 and thus its fruiting ability is unknown.

\subsection{Conclusions}

The ability to fruit heterothallic $A$. mellea in vitro will assist future research by reliably providing basidiospores of a known genotype for use in transformation studies, ending reliance on sporadically available wild-collected basidiospores. The knowledge of the mechanisms controlling in vitro production of $A$. mellea fruiting bodies may also assist with fruiting of other Armillaria species that are difficult to fruit in culture. Furthermore, the evaluation of suitable $A$. tumefaciens strains for transformation, and the construction of a versatile vector, should facilitate future genetic research investigating fluorescent protein expression and gene silencing in this important pathogenic species.

\section{Acknowledgements}

This research was funded in part by the Royal Horticultural Society and United States Department of Agriculture and was conducted under the DEFRA Plant Health Licence PHL 51046/198767/2.

\section{References}

Abomo-Ndongo S, Mohammed C, Guillaumin JJ,1997. Sexual behaviour of Armillaria heimii and A. mellea isolates from Africa. European Journal of Plant Pathology 27: 207-224.

Ali S, 2015. Investigating secondary metabolism in Zymoseptoria tritici. PhD thesis. University of Bristol, Bristol, UK. 
Anderson J, 1982. Bifactorial heterothallism and vegetative diploidy in Clitocybe tabescens. Mycologia 74: 911-916.

Anderson JB, Ullrich RC, 1979. Biological Species of Armillaria mellea in North America. Mycologia 71: $402-414$.

Arjona D, Aragón C, Aguilera JA, Ramíre L, Pisabarro AG, 2009. Reproducible and controllable light induction of in vitro fruiting of the white-rot basidiomycete Pleurotus ostreatus. Mycological Research 113: 552-558.

Baumgartner K, 2004. Root collar excavation for postinfection control of Armillaria root disease of grapevine. Plant Disease 88: 1235-1240

Baumgartner K., Baker BR, Korhonen K, Zhao J, Hughes KW, Bruhn J, Bowman, TS, Bergemann SE, 2012. Evidence of natural hybridization among homothallic members of the basidiomycete Armillaria mellea sensu stricto. Fungal Biology 116: 677-91.

Baumgartner K, Coetzee MPA, Hoffmeister D, 2011. Secrets of the subterranean pathosystem of Armillaria. Molecular Plant Pathology 12: 515-534.

Baumgartner K, Fujiyoshi P, Foster GD, Bailey AM, 2010. Agrobacterium tumefaciens-mediated transformation for investigation of somatic recombination in the fungal pathogen Armillaria mellea. Applied and Environmental Microbiology 76: 7990-7996.

Bundock P, den Dulk-Ras A, Beijersbergen A, Hooykaas PJ, 1995. Trans-kingdom T-DNA transfer from Agrobacterium tumefaciens to Saccharomyces cerevisiae. The EMBO Journal 14: 3206-3214.

Burns C, Gregory KE, Kirby M, Cheung MK, Riquelme M, Elliott TJ, Challen MP, Bailey AM, Foster GD, 2005. Efficient GFP expression in the mushrooms Agaricus bisporus and Coprinus cinereus requires introns. Fungal Genetics and Biology 42: 191-199.

Burns C, Leach KM, Elliott TJ, Challen MP, Foster GD, Bailey AM, 2006. Evaluation of Agrobacterium-mediated transformation of Agaricus bisporus using a range of promoters linked to hygromycin resistance. Molecular Biotechnology 32: 129-138.

Cha J, Igarashi T, 1995. A note on Armillaria mellea subsp. nipponica subsp. nov. in Japan. Mycoscience 35: 143-146.

Chen X, Stone M, Schlagnhaufer C, Romaine CP, 2000. A fruiting body tissue method for efficient Agrobacterium-mediated transformation of Agaricus bisporus. Applied and Environmental Microbiology 66: 4510-4513.

Coetzee MPA, Wingfield BD, Harrington TC, Steimel J, Coutinho TA, Wingfield MJ, 2001. The root rot fungus Armillaria mellea introduced into South Africa by early Dutch settlers. Molecular Ecology 10: 387-396.

Collins C, Keane TM, Turner DJ, O’Keeffe G, Fitzpatrick DA, Doyle S, 2013. Genomic and proteomic dissection of the ubiquitous plant pathogen, Armillaria mellea: toward a new infection model system. Journal of Proteome Research 12: 2552-2570.

Collins CM, Heneghan MN, Kilaru S, Bailey AM, Foster GD, 2010. Improvement of the Coprinopsis cinerea molecular toolkit using new construct design and additional marker genes. Journal of Microbiological Methods 82: 156-62. 
Eastwood DC, Herman B, Noble R, Dobrovin-Pennington A, Sreenivasaprasad S, Burton KS 2013. Environmental regulation of reproductive phase change in Agaricus bisporus by 1-octen-3-ol, temperature and CO2. Fungal Genetics and Biology 55: 54-66.

Gietz RD, Woods R, 2002. Transformation of yeast by lithium acetate/single-stranded carrier DNA/polyethylene glycol method. Methods in Enzymology 350: 87-96.

Grillo R, Korhonen K, Hantula J, Hietala AM, 2000. Genetic evidence for somatic haploidization in developing fruit bodies of Armillaria tabescens. Fungal Genetics and Biology 30: 135-145.

Guillaumin JJ, Anderson JB, Korhonen K, 1991. Life cycle, interfertility, and biological Species. In: Shaw CG III, Kile GA (eds), Armillaria Root Disease. Washington, DC: United States Department of Agriculture Forest Service Agriculture Handbook No. 691, pp. 10-47.

Harrington TC, Wingfield BD, 1995. A PCR-based identification method for species of Armillaria. Mycologia 87: 280-288.

Heneghan MN, Porta C, Zhang C, Burton KS, Challen MP, Bailey AM, Foster GD, 2009. Characterization of serine proteinase expression in Agaricus bisporus and Coprinopsis cinerea by using green fluorescent protein and the A. bisporus SPR1 promoter. Applied and Environmental Microbiology 75: 792-801.

Kilaru S, Collins CM, Hartley AJ, Bailey AM, Foster GD, 2009. Establishing molecular tools for genetic manipulation of the pleuromutilin-producing fungus Clitopilus passeckerianus. Applied and Environmental Microbiology 75: 7196-204.

Kilaru S, Hoegger PJ, Majcherczyk A, Burns C, Shishido K, Bailey AM, Foster GD, Kües U, 2006. Expression of laccase gene Icc1 in Coprinopsis cinerea under control of various basidiomycetous promoters. Applied Microbiology and Biotechnology 71: 200-210.

Kile GA, Guillaumin JJ, Mohammed C, Watling R, 1994. Biogeography and pathology of Armillaria. In: Johannson M, Stenlid J (eds), Proceedings of the 8th International Conference on Root and Butt Rots. Swedish University of Agricultural Sciences, Uppsala, Vik, Sweden and Haikko, Finland, pp. 411-436

Korhonen K, 1978. Infertility and clonal size in the Armillariella mellea complex. Karstenia 18: 31-42.

Korhonen K, Hintikka V, 1974. Cytological evidence for somatic diploidization in dikaryotic cells of Armillariella mellea. Archives of Microbiology 95: 187-192.

Kües U, Liu Y, 2000. Fruiting body production in Basidiomycetes. Applied Microbiology and Biotechnology 54: 141-52.

Lazo GR, Stein PA, Ludwig RA, 1991. A DNA transformation-competent Arabidopsis genomic library in Agrobacterium. Biotechnology 9: 963-967.

Liu D, Coloe S, Baird R, Pedersen J, 2000. Rapid mini-preparation of fungal DNA for PCR. Journal of Clinical Microbiology 38: 471.

Morrison DJ, 2004. Rhizomorph growth habit, saprophytic ability and virulence of 15 Armillaria species. Forest Pathology 34:15-26.

Nakazawa T, Miyazaki Y, Kaneko S, Shishido K, 2008. Stimulative effects of light and a temperature downshift on transcriptional expressions of developmentally regulated genes in the initial stages of fruiting-body formation of the basidiomycetous mushroom Lentinula edodes. FEMS Microbiology Letters 289: 67-71. 
Ota Y, Fukuda K, Suzuki K, 1998. The nonheterothallic life cycle of Japanese Armillaria mellea. Mycologia 90: 396-405.

Otieno W, Perez-Sierra A, Termorshuizen A, 2003. Characterization of Armillaria isolates from tea (Camellia sinensis) in Kenya. Mycologia 95:160-175.

Perez-Sierra A, Guillaumin JJ, Spooner B, Bridge P, 2004. Characterization of Armillaria heimii from Africa. Plant Pathology 53: 220-230.

Qin GF, Zhao J, Korhonen K, 2007. A study on intersterility groups of Armillaria in China. Mycologia 99: 430-441.

Reaves JL, McWilliams M, 1991. In vitro fruiting of Armillaria species. Research Note, USDA, Pacific Northwest Research Station, 1-8.

Rhoads A, 1925. Root rot of the grapevine in Missouri caused by Clitocybe tabescens (Scop.) Bres. Journal of Agricultural Research XXX: 345-364.

Rhoads A, 1945. A comparative study of two closely related root-rot fungi, Clitocybe tabescens and Armillaria mellea. Mycologia 37: 741-766.

RHS (Royal Horticultural Society), 2015. Studies on the pathogenicity of Armillaria species. Retrieved on $5^{\text {th }}$ of January 2015 from: https://www.rhs.org.uk/science/plant-health-in-gardens/pathology /projects/pathogenicity-of-armillaria-species.

Shaw CG III, MacKenzie M, Toes EHA, Hood IA, 1981. Cultural characteristics and pathogenicity to Pinus radiata of Armillaria novae-zelandiae and A. limonea. New Zealand Journal of Forestry Science 11: 65-70.

Shim JO, Chang KC, Lee YS, Park CH, Kim HY, Lee UY, Lee TS, Lee MW, 2006. The fruiting body formation of Armillaria mellea on oak sawdust medium covered with ground raw carrots. The Korean Society of Mycology 34: 206-208.
Table 1 - Isolates of Armillaria gallica and A. mellea used in this study

\begin{tabular}{|c|c|c|c|c|}
\hline Taxon & Isolate & Location & Host & $\begin{array}{c}\text { Collector(s) } / \\
\text { Reference } / \text { Year }\end{array}$ \\
\hline A. gallica & ANA220 & UK & Acer sp. & RHS, 2003 \\
\hline
\end{tabular}




\begin{tabular}{|c|c|c|c|c|}
\hline \multirow[t]{3}{*}{ (heterothallic) } & CG024 & Surrey, UK & Acer sp. & RHS, 2004 \\
\hline & CG263 & Yorkshire, UK & Rhizomorphs & RHS, 2006 \\
\hline & CG645 & North Ayrshire, UK & Acer sp. & RHS, 2007 \\
\hline \multirow{4}{*}{$\begin{array}{c}\text { A. mellea } \\
\text { (heterothallic) }\end{array}$} & CG440 & Surrey, UK & Ligustrum sp. & RHS, 2006 \\
\hline & NAPA187 & California, USA & Quercus kelloggii & K. Baumgartner, 2007 \\
\hline & ELDO17 & California, USA & Vitis sp. & K. Baumgartner, 2000 \\
\hline & ELDO19 & California, USA & Vitis sp. & K. Baumgartner, 2000 \\
\hline \multirow{3}{*}{$\begin{array}{l}\text { A. mellea ssp. } \\
\text { africana } \\
\text { (homothallic) }\end{array}$} & 03468/T1 [ST1] & Sao Tome, Africa & Theobroma cacao & M. Ivory \\
\hline & 03469/T1 [K5] & Kenya, Africa & Cupressus funebris & I.A.S. Gibson, 1958 \\
\hline & 03470/T1 [K8] & Kenya, Africa & Grevillea robusta & M. Ivory \\
\hline \multirow{3}{*}{$\begin{array}{l}\text { Chinese Biological } \\
\text { Species G } \\
\text { (homothallic) }\end{array}$} & $03332 / 2$ & Yunnan province, China & Rhododendron sp. & G-F. Qin, J. Zhao, 2003 \\
\hline & $03345 / 1$ & Hubei province, China & Ailanthus altissima & J. Zhao, 2003 \\
\hline & $03371 / 1$ & Guangxi province, China & Broadleaf tree & J. Zhao, 2003 \\
\hline $\begin{array}{l}\text { A. mellea ssp. } \\
\text { nipponica } \\
\text { (homothallic) }\end{array}$ & $03384 / 2$ & Japan & Unknown & G-F. Qin, 2003 \\
\hline \multirow{10}{*}{$\begin{array}{l}\text { Armillaria mellea } \\
\text { (heterothallic, } \\
\text { transgenic) }\end{array}$} & Napa187xR1PT2 & \multirow{6}{*}{$\mathrm{n} / \mathrm{a}$} & \multirow{6}{*}{$\mathrm{n} / \mathrm{a}$} & \multirow{6}{*}{$\begin{array}{l}\text { Baumgartner et al. } \\
\qquad(2010)\end{array}$} \\
\hline & Napa187xR1PT4 & & & \\
\hline & Napa187xR1PT5 & & & \\
\hline & Napa187xR1PT6 & & & \\
\hline & Napa187xR2PT2 & & & \\
\hline & Napa187xR2PT3 & & & \\
\hline & pB1 & \multirow{4}{*}{$\mathrm{n} / \mathrm{a}$} & \multirow{4}{*}{$\mathrm{n} / \mathrm{a}$} & \multirow{4}{*}{ This paper } \\
\hline & pM1 & & & \\
\hline & 15.2 & & & \\
\hline & 16.1 & & & \\
\hline
\end{tabular}

530

531

532

533

534

535

536

537

538

539

540

541

Table 2 - Vectors used in transformations

\begin{tabular}{|c|c|c|c|c|}
\hline \multicolumn{5}{|c|}{ Table 2 - Vectors used in transformations } \\
\hline Plasmid & Promoter & $\begin{array}{c}\text { Hygromycin } \\
\text { resistance gene }\end{array}$ & Terminator & Reference \\
\hline pBGgHg & Agaricus bisporus gpdll & Full length & CaMV 35S & Chen et al. \\
\hline
\end{tabular}

Ford et al., Fungal Biology, page 15 


\begin{tabular}{|c|c|c|c|c|}
\hline & & & & $(2000)$ \\
\hline pGR4-4iGM3 & Agaricus bisporus gpdII & Truncated & $\begin{array}{c}\text { Aspergillus } \\
\text { nidulans trpC }\end{array}$ & $\begin{array}{c}\text { Burns et al. } \\
\text { (2005) }\end{array}$ \\
\hline pCAM-hph-Pcgpd & $\begin{array}{c}\text { Phanerochaete } \\
\text { chrysosporium gpd }\end{array}$ & Truncated & $\begin{array}{c}\text { Aspergillus } \\
\text { nidulans trpC }\end{array}$ & This paper \\
\hline pCAM-hph-series & Agaricus bisporus gpdII & Full length & CaMV 35S & This paper \\
\hline
\end{tabular}

549

550

551

552

553

554

555

556

557

558

559

560

561

562

Table 3 - Fruiting of isolates in preliminary studies 


\begin{tabular}{|c|c|c|c|c|c|c|}
\hline & & Oranges & $\begin{array}{l}\text { Rice, sawdust } \\
\text { and peptone } \\
\text { (RSP) }\end{array}$ & $\begin{array}{l}\text { Rice, sawdust } \\
\text { and carrot } \\
\text { (RSC) }\end{array}$ & $\begin{array}{l}\text { Rice, sawdust } \\
\text { and tomato } \\
\text { (RST) }\end{array}$ & $\begin{array}{l}\text { Rice, sawdust } \\
\text { pearl barley, } \\
\text { corn and carrot } \\
\text { (RSBCC) }\end{array}$ \\
\hline \multirow{4}{*}{ A. gallica } & ANA220 & $0 \%^{a}$ & $0 \%^{\mathrm{c}}$ & $0 \%^{b}$ & $0 \%{ }^{\mathrm{e}}$ & $\mathrm{n} / \mathrm{a}$ \\
\hline & CG024 & $0 \%^{a}$ & $\mathrm{n} / \mathrm{a}$ & $0 \%^{a}$ & $0 \%{ }^{\mathrm{e}}$ & $\mathrm{n} / \mathrm{a}$ \\
\hline & CG263 & $0 \%^{a}$ & $\mathrm{n} / \mathrm{a}$ & $0 \%^{a}$ & $0 \%^{\mathrm{e}}$ & $\mathrm{n} / \mathrm{a}$ \\
\hline & CG645 & $0 \%^{a}$ & $\mathrm{n} / \mathrm{a}$ & $100 \%$ primordia $^{a}$ & $25 \%$ primordia $^{e}$ & $\mathrm{n} / \mathrm{a}$ \\
\hline \multirow{4}{*}{ A. mellea } & CG440 & $0 \%^{b}$ & $0 \%^{a}$ & $0 \%^{a}$ & $\begin{array}{l}50 \% \text { immature } \\
\text { fruiting bodies }\end{array}$ & $\mathrm{n} / \mathrm{a}$ \\
\hline & ELDO17 & $0 \%^{a}$ & $0 \%^{a}$ & $\begin{array}{l}100 \% \text { immature } \\
\text { fruiting bodies }^{\text {a }}\end{array}$ & $\begin{array}{c}33 \% \text { mature } \\
\text { fruiting bodies }\end{array}$ & $\begin{array}{l}33 \% \text { Immature } \\
\text { fruiting bodies }\end{array}$ \\
\hline & ELDO19 & $0 \%^{a}$ & $0 \%^{b}$ & $0 \%^{a}$ & $\begin{array}{l}100 \% \text { immature } \\
\text { fruiting bodies }^{a}\end{array}$ & $\mathrm{n} / \mathrm{a}$ \\
\hline & NAPA187 & $0 \%^{a}$ & $n / a$ & $0 \%^{\mathrm{b}}$ & $0 \%^{\mathrm{e}}$ & $n / a$ \\
\hline
\end{tabular}

566

567

568

569

570

571

572

573

574

575

576

577

578

579

580

\section{2}

\section{4}

75

\section{6}

\section{7}

78

580
Where superscript $=\mathbf{a} n=1$, experiment not repeated; $\mathbf{b} n=2$, experiment repeated once; $\mathbf{c} n=3$, experiment not repeated; $\mathbf{d} n=3$, experiment repeated once; $\mathbf{e} n=4$, experiment repeated once

6

7

568

69

70

71

Table 4 - Conditions used for light and temperature reduction experiment for fruiting body production in ELDO17 on RST medium

\begin{tabular}{l|l|l|l} 
Condition & First condition & Second condition & Temperature or light
\end{tabular}




\begin{tabular}{|c|c|c|c|}
\hline & & & $\begin{array}{l}\text { reduction } \\
\end{array}$ \\
\hline 1 & $23^{\circ} \mathrm{C}, 125 \mu \mathrm{mol} \mathrm{m}{ }^{-2} \mathrm{~s}^{-1}$ & $\mathrm{n} / \mathrm{a}$ & $\begin{array}{l}\text { Constant warm/bright; no } \\
\text { light or temperature reduction }\end{array}$ \\
\hline 2 & $23^{\circ} \mathrm{C}, 5 \mu \mathrm{mol} \mathrm{m} \mathrm{m}^{-2} \mathrm{~s}^{-1}$ & $\mathrm{n} / \mathrm{a}$ & $\begin{array}{l}\text { Constant warm/dim; no light } \\
\text { or temperature reduction }\end{array}$ \\
\hline 3 & $23^{\circ} \mathrm{C}$, dark & $\mathrm{n} / \mathrm{a}$ & $\begin{array}{l}\text { Constant warm/dark; no light } \\
\text { or temperature reduction }\end{array}$ \\
\hline 4 & $23^{\circ} \mathrm{C}, 125 \mu \mathrm{mol} \mathrm{m}{ }^{-2} \mathrm{~s}^{-1}$ & $23^{\circ} \mathrm{C}, 5 \mu \mathrm{mol} \mathrm{m} \mathrm{m}^{-2}$ & $\begin{array}{c}\text { Warm/bright to warm/dim; } \\
\text { light reduction }\end{array}$ \\
\hline 5 & $23^{\circ} \mathrm{C}, 125 \mu \mathrm{mol} \mathrm{m}{ }^{-2} \mathrm{~s}^{-1}$ & $15^{\circ} \mathrm{C}, 125 \mu \mathrm{mol} \mathrm{m}{ }^{-2} \mathrm{~s}^{-1}$ & $\begin{array}{c}\text { Warm/bright to cool/bright; } \\
\text { temperature reduction }\end{array}$ \\
\hline 6 & $23^{\circ} \mathrm{C}, 125 \mu \mathrm{mol} \mathrm{m}{ }^{-2} \mathrm{~s}^{-1}$ & $15^{\circ} \mathrm{C}, 5 \mu \mathrm{mol} \mathrm{m} \mathrm{m}^{-2} \mathrm{~s}^{-1}$ & $\begin{array}{l}\text { Warm/bright to cool/dim; light } \\
\text { and temperature reduction }\end{array}$ \\
\hline 7 & $23^{\circ} \mathrm{C}, 5 \mu \mathrm{mol} \mathrm{m} \mathrm{m}^{-2} \mathrm{~s}^{-1}$ & $15^{\circ} \mathrm{C}, 5 \mu \mathrm{mol} \mathrm{m} \mathrm{m}^{-2} \mathrm{~s}^{-1}$ & $\begin{array}{l}\text { Warm/dim to cool/dim; } \\
\text { temperature reduction }\end{array}$ \\
\hline 8 & $23^{\circ} \mathrm{C}$, dark & $15^{\circ} \mathrm{C}$, dark & $\begin{array}{l}\text { Warm/dark to cool/dark; } \\
\text { temperature reduction }\end{array}$ \\
\hline 9 & $\begin{array}{l}\text { [initially colonised at RT] } \\
15^{\circ} \mathrm{C}, 125 \mu \mathrm{mol} \mathrm{m} \mathrm{m}^{-2} \mathrm{~s}^{-1}\end{array}$ & $15^{\circ} \mathrm{C}, 5 \mu \mathrm{mol} \mathrm{m} \mathrm{m}^{-2} \mathrm{~s}^{-1}$ & $\begin{array}{l}\text { Cool/bright to cool/dim; light } \\
\text { reduction }\end{array}$ \\
\hline 10 & $\begin{array}{c}\text { [initially colonised at } 15^{\circ} \mathrm{C} \text { ] } \\
15^{\circ} \mathrm{C}, 125 \mu \mathrm{mol} \mathrm{m} \mathrm{s}^{-1}\end{array}$ & $15^{\circ} \mathrm{C}, 5 \mu \mathrm{mol} \mathrm{m} \mathrm{m}^{-2} \mathrm{~s}^{-1}$ & $\begin{array}{l}\text { Cool/bright to cool/dim; light } \\
\text { reduction }\end{array}$ \\
\hline 11 & $15^{\circ} \mathrm{C}, 125 \mu \mathrm{mol} \mathrm{m}{ }^{-2} \mathrm{~s}^{-1}$ & $\mathrm{n} / \mathrm{a}$ & $\begin{array}{l}\text { Constant cool/bright; no light } \\
\text { or temperature reduction }\end{array}$ \\
\hline 12 & $15^{\circ} \mathrm{C}, 5 \mu \mathrm{mol} \mathrm{m} \mathrm{m}^{-2} \mathrm{~s}^{-1}$ & $\mathrm{n} / \mathrm{a}$ & $\begin{array}{c}\text { Constant cool/dim; no light or } \\
\text { temperature reduction }\end{array}$ \\
\hline 13 & $15^{\circ} \mathrm{C}$, dark & $\mathrm{n} / \mathrm{a}$ & $\begin{array}{l}\text { Constant cool/dark; no light } \\
\text { or temperature reduction }\end{array}$ \\
\hline
\end{tabular}

581

582

583

584

585

586

587

588

589

590

591

592

593

Table 5 - Fruiting of homothallic and transgenic isolates in RST medium 


\begin{tabular}{|c|c|c|}
\hline Species & Isolate & Fruiting bodies produced \\
\hline \multirow{3}{*}{$\begin{array}{l}\text { Chinese Biological } \\
\text { Species G } \\
\text { (homothallic) }\end{array}$} & $03332 / 2$ & No primordia produced ${ }^{\mathrm{b}}$ \\
\hline & $03345 / 1$ & No primordia produced ${ }^{a}$ \\
\hline & $03371 / 1$ & No primordia produced ${ }^{a}$ \\
\hline $\begin{array}{c}\text { A. mellea ssp. } \\
\text { nipponica } \\
\text { (homothallic) }\end{array}$ & $03384 / 2$ & $100 \%$ Mature fruiting bodies ${ }^{b}$ \\
\hline \multirow{3}{*}{$\begin{array}{l}\text { A. mellea ssp. } \\
\text { africana } \\
\text { (homothallic) }\end{array}$} & 03468/T1 & $75 \%$ Mature fruiting bodies ${ }^{a}$ \\
\hline & 03469/T1 & $75 \%$ Mature fruiting bodies ${ }^{a}$ \\
\hline & 03470/T1 & $83 \%$ Mature fruiting bodies ${ }^{b}$ \\
\hline \multirow{6}{*}{$\begin{array}{l}\text { Isolates generated } \\
\text { from pairing diploid } \\
\text { WT NAPA187 with } \\
\text { haploid transgenic } \\
\text { isolates derived from } \\
\text { Son202 }\end{array}$} & Napa187xR1PT2 & No primordia produced ${ }^{b}$ \\
\hline & Napa187xR1PT4 & No primordia produced ${ }^{\mathrm{b}}$ \\
\hline & Napa187xR1PT5 & No primordia produced $^{a}$ \\
\hline & Napa187xR1PT6 & No primordia produced ${ }^{a}$ \\
\hline & Napa187xR2PT2 & No primordia produced $^{a}$ \\
\hline & Napa187xR2PT3 & No primordia produced ${ }^{\mathrm{a}}$ \\
\hline \multirow{4}{*}{ Transgenic isolates } & $\mathrm{pB} 1$ & $33 \%$ Immature fruiting bodies ${ }^{c}$ \\
\hline & pM1 & $100 \%$ Immature fruiting bodies ${ }^{c}$ \\
\hline & 15.2 & $100 \%$ Immature fruiting bodies ${ }^{d}$ \\
\hline & 16.1 & $100 \%$ Immature fruiting bodies ${ }^{d}$ \\
\hline
\end{tabular}

596

597

598

599

600

601

602

603

604

605

606

607

608

609

610

611

a $n=4$, experiment not repeated; $\mathbf{b} n=6$, experiment repeated once; $\mathbf{c} n=3$, experiment not repeated; $\mathbf{d} \mathrm{n}=2$, experiment not repeated;

\section{7}

8

99

00

01

2

3

5

06

07

\section{8}

09

11

Figure 1: In vitro fruiting bodies produced on RST medium. A Clusters of heterothallic ELDO17 primordia and small immature fruiting bodies; B Mature ELDO17 fruiting bodies; C Mature harvested 
fruiting bodies of ELDO17; D Mature fruiting bodies of homothallic African isolate 03470/T1; E Mature fruiting bodies of homothallic Japanese isolate $03384 / 2$

\section{Figure 2: The percentage of heterothallic $A$. mellea ELDO17 and ELDO19 cultures that} produced primordia (A) and mature fruiting bodies $(B)$ on various media following a combined light and temperature reduction.

Error bars represent standard error from the mean. RSP = rice, sawdust and peptone medium; RSC = rice, sawdust and carrot medium; RST = rice, sawdust and tomato medium

Figure 3: Percentage of heterothallic A. mellea ELDO17 cultures that produce mature fruiting bodies under different light and temperature regimes on RST medium. $n=3$ to 6 .

Figure 4: Days until primordia emergence on RST medium for different $A$. mellea isolates after movement into second growth room.

Error bars represent standard error from the mean.

Figure 5: Average colony diameter of selected transformants with different plasmids grown on PDA + $30 \mu \mathrm{g} / \mathrm{ml}$ hygromycin after three weeks.

$\mathrm{n}=9$ and error bars represent standard error from the mean. Letters above bars indicate significant differences between groups as determined by Tukey's HSD test following one-way ANOVA where $P=$ $<0.05$. 
Figure 1

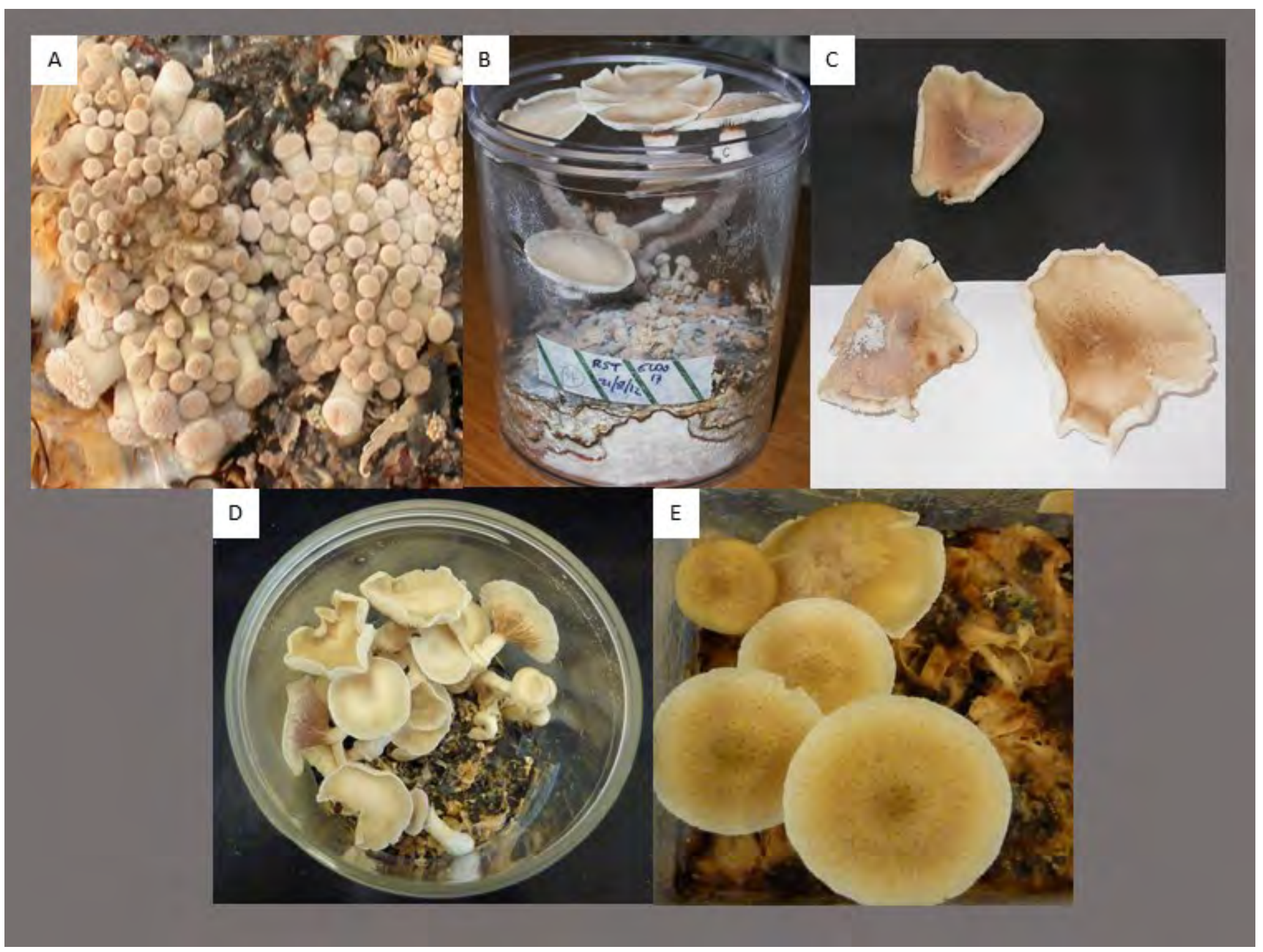


Figure 2

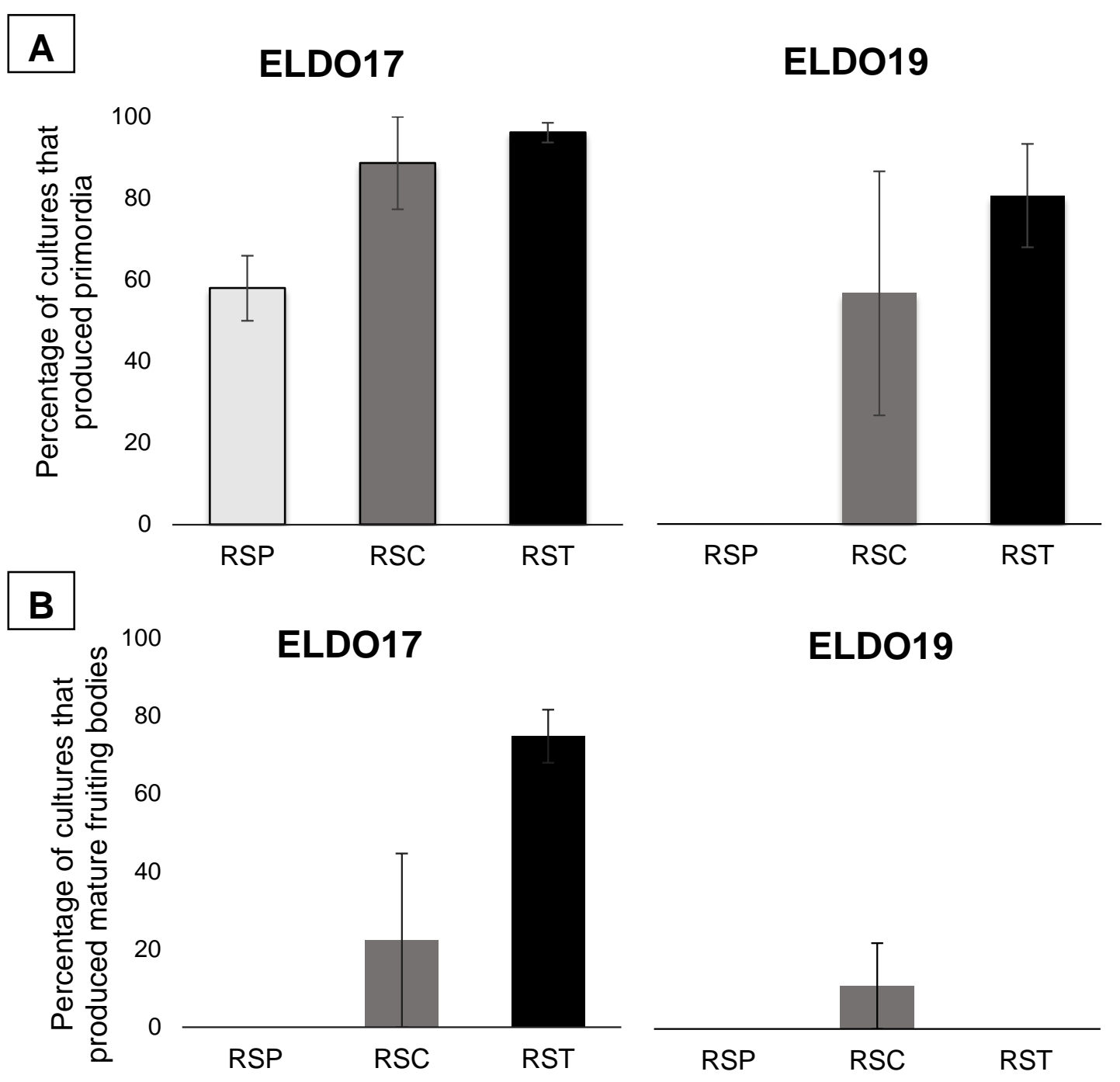


Figure 3

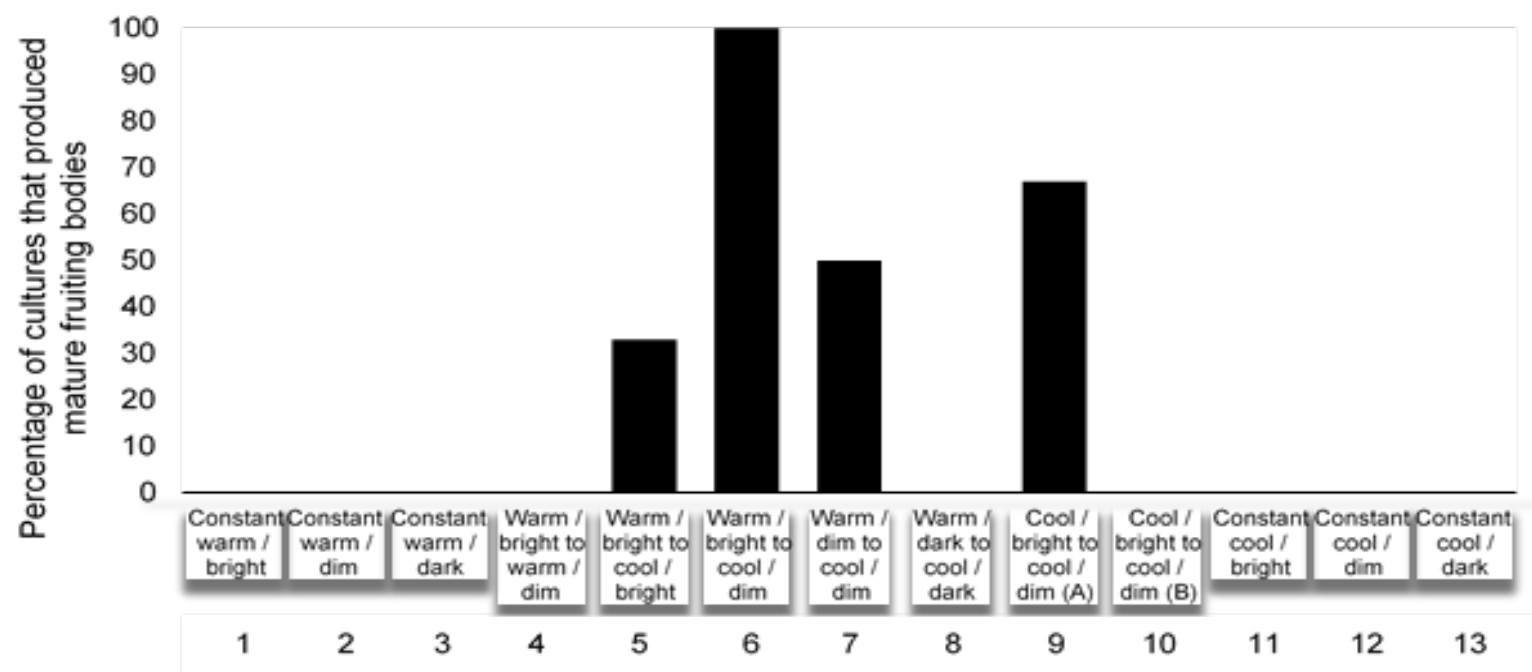


Figure 4

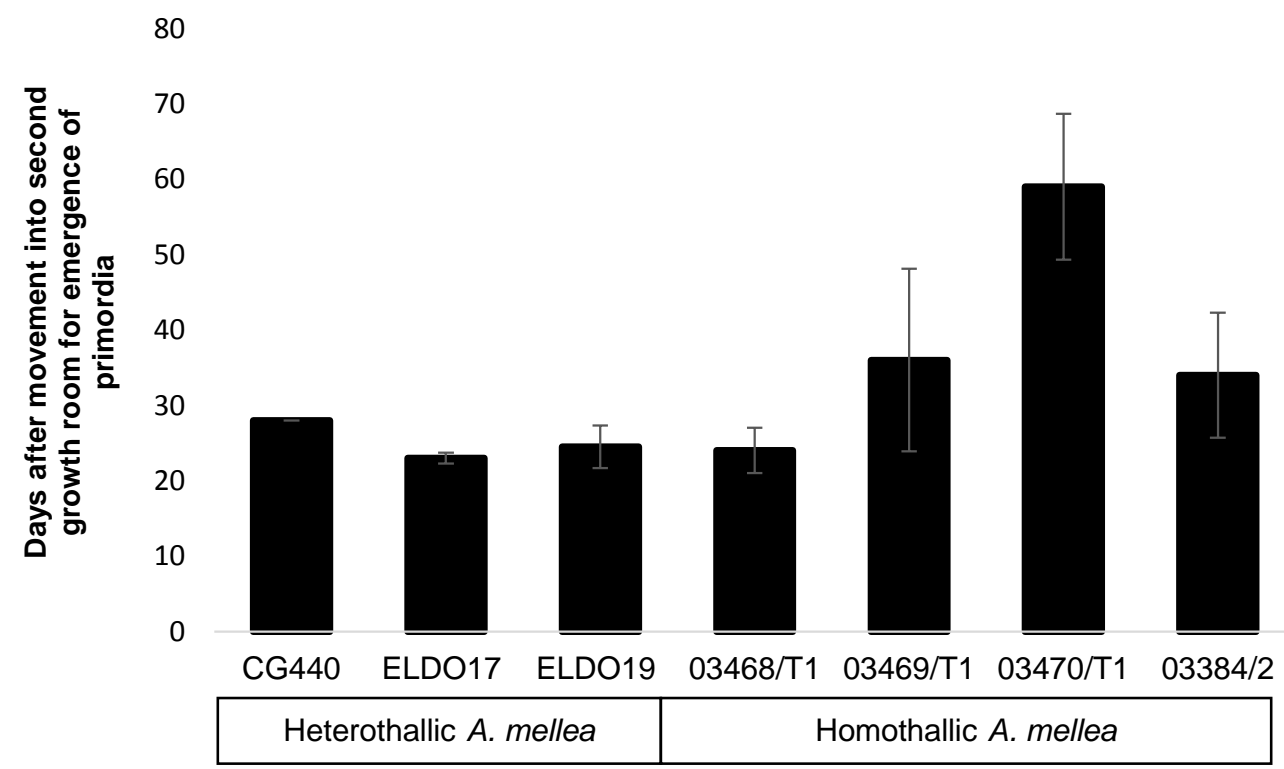


Figure 5

A

3

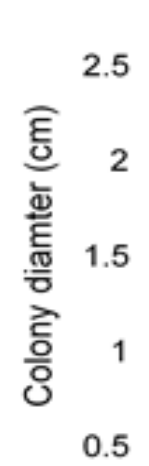

0

pBGgHg (Ab gpd pGR4-4IGM3 (Ab gpd promoter with full-length promoter with truncated hph)

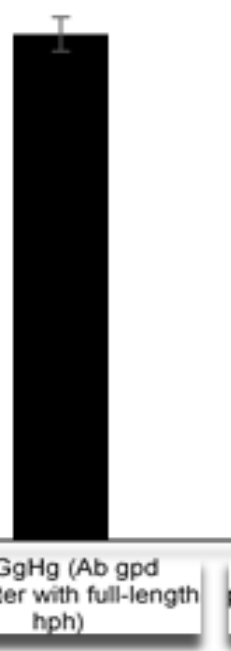
hoh

B

B

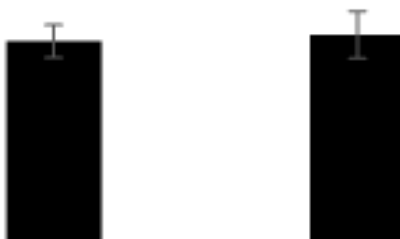

A \begin{tabular}{c|c} 
PCAM-hph-Pcgpd (PC \\
gpd promoter with
\end{tabular}$\quad \begin{aligned} & \text { PCAM-hph-series (Ab gpd } \\
& \text { promoter with full-length }\end{aligned}$ truncated hph) 